\title{
Virus Zika, ¿culpable o inocente?
}

\author{
Cecilia Perret
}

\author{
Zika virus, guilty or innocent?
}

$\mathrm{E}$ 1 virus Zika, hasta enero de este año 2016 era un perfecto desconocido hasta que saltó a la fama por el brote en Brasil y su aparente relación con la microcefalia congénita.

Rápidamente nos fuimos llenando de información; el virus está en Brasil, y se está diseminando, lo transmite un mosquito, produce microcefalia en los recién nacidos, parece que se puede trasmitir por vía sexual. Así, de ser un desconocido, pasó a ser protagonista de los titulares en la prensa, en las conversaciones de pasillo y en las reuniones clínicas

\section{¿Pero qué hay detrás de este virus Zika?}

Es identificado por primera vez en 1947 cuando fue aislado de un mono Macaco rhesus en el Zika Forest Reasearch Institute, en Uganda, cuando se estudiaba a un mono febril con sospecha de fiebre amarilla. De ahí toma su nombre. El primer aislamiento en humanos fue en 1969 en un paciente de Nigeria. Desde entonces casos aislados se reportaron en África y en menor extensión en el Sudeste Asiático

Es un virus ARN, perteneciente a la familia Flaviviridae, muy cercano genéticamente al virus dengue. Tiene dos linajes genéticos, africano y asiático. Es trasmitido por la hembra Aedes aegyptii y albopictus ampliamente distribuidos en América Latina y Caribe.

La gran mayoría de las personas infectadas, aproximadamente $80 \%$, no presenta síntomas. En los sintomáticos la enfermedad aparece luego de un período de incubación de hasta 12 días siendo auto-limitada en aproximadamente cinco días. El síntoma principal es el exantema máculopapular, muy frecuentemente pruriginoso. Se puede acompañar de fiebre más bien baja, presente en cerca de 30\% de los casos, cefalea, mialgias, conjuntivitis y artralgias o artritis, principalmente de manos. La duración es de aproximadamente una semana curando completamente sin complicaciones.

En el año 2007 se registró el primer gran brote en las islas Yap de la Micronesia, estimándose que afectó a 73\% de la población mayor de tres años, con casi 185 casos confirmados sin describir complicaciones. Posteriormente se detectó un brote de mayor magnitud en la Polinesia
Francesa durante octubre 2013 y hasta abril del 2014, con más de 32.000 casos, todos ellos leves. Se estimó una tasa de ataque de $66 \%$. Fue considerada una enfermedad banal, auto-limitada, aunque se advirtió por primera vez la probable asociación de virus Zika con el síndrome de Guillain Barré (SGB) ${ }^{1}$. En un estudio posterior, caso control, realizado del brote de la Polinesia se confirmó fuerte asociación del virus Zika con esta enfermedad neurológica ${ }^{2}$. En este estudio se estimó el riesgo de SGB en $1 / 4.000$ casos y se descartó una mayor probabilidad de padecerlo en paciente previamente infectados con virus dengue. La mediana de aparición de esta complicación fue de seis días posteriores al cuadro de Zika. Noventa y tres por ciento de los pacientes con SGB tenían IgM positiva para Zika comparado con $17 \%$ de los pacientes controles. Durante el brote actual en el continente Americano, 12 países han reportado aumento de los casos de SGB en forma concomitante con la trasmisión local de virus Zika.

Cómo era esperable, luego del brote de Zika en la Polinesia Francesa, específicamente en Tahiti, a comienzos del 2014 se reportan los primeros casos de Zika autóctonos en la Isla de Pascua. En ese brote se identificaron 173 casos, 51 confirmados por reacción de polimerasa en cadena en el Instituto de Salud Pública ${ }^{3}$. La secuenciación del virus mostró que es idéntico al de la Polinesia Francesa concluyéndose que ésta fue muy probablemente la puerta de entrada, al igual que lo ocurrido en el brote de dengue en la isla el año $2002^{4}$.

El virus alcanza el continente Americano a comienzos de 2015 cuando se reportan los primeros casos en el norte de Brasil (Natal), aunque se describieron casos en el norte de Brasil sugerentes de Zika desde octubre del 2014. El análisis filogenético muestra un virus de linaje asiático muy similar al de la Polinesia Francesa ${ }^{5}$. Desde entonces, hasta fines de marzo de 2016, 33 países americanos reportan trasmisión autóctona del virus diseminándose muy rápidamente.

Es Brasil quien lanza la alerta de probable asociación del virus Zika con infección congénita y grave daño neurológico en el feto y la consecuente microcefalia. $\mathrm{La}$ OMS decreta al brote por virus Zika como una emergencia sanitaria por su relación con el daño neurológico grave en fetos producto de la infección congénita. La información publicada hasta la fecha confirma esta causalidad. Un
Pontificia Universidad Católica de Chile. Escuela de Medicina.

Recibido: 1 de abril de 2016. Aceptado: 8 de abril de 2016

\section{Correspondencia a:} Cecilia Perret Pérez cperret@med.puc.cl 
estudio retrospectivo de la Polinesia Francesa demuestra mayor riesgo de microcefalia en fetos cuyas madres adquirieron la infección en el primer trimestre del embarazo $^{6}$. Descripciones iniciales de 35 casos de niños con microcefalia en madres que habían estado en zona de Zika en Brasil, muestran que sobre 70\% de los niños tenía perímetro craneano -3DS y todos tenían alguna alteración neurológica en el estudio imagenológico. Fuera del sistema central sólo se describió alteraciones tipo artrogriposis y pie equino ${ }^{7}$. Un estudio caso y control prospectivo de seguimiento de mujeres embarazadas con infección confirmada de virus Zika mostró preliminarmente que de las 42 mujeres infectadas, $29 \%$ tenía hasta el momento del seguimiento alguna alteración fetal, la mayoría de ellas neurológicas, incluidas muertes fetales. Ninguno de las mujeres controles mostró alteraciones imagenológicas en el seguimiento de su embarazo ${ }^{8}$. Se ha encontrado virus Zika en líquido amniótico y en tejido cerebral de niños mortinatos. También se han reportado alteraciones fetales en viajeras embarazadas que enfermaron con virus Zika. En seis de ellas que se infectaron el primer trimestre, dos presentaron abortos espontáneos, dos terminaron electivamente el embarazo, una con recién nacido con microcefalia y la otra continúa en seguimiento. De tres mujeres infectadas en el segundo y tercer trimestre dos han tenido recién nacidos sanos y una continúa en

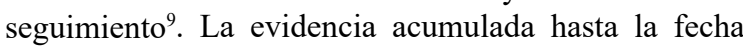
confirma trasmisión congénita del virus con un marcado neurotropismo y causalidad en el daño cerebral con la consecuente microcefalia.

$\mathrm{Si}$ a este escenario le agregamos la confirmación de casos por trasmisión sexual en al menos siete países incluidos Chile, agregando así un riesgo de infección en individuos que viven en países donde no existe el vector, tenemos que este virus Zika no es tan inocente como pensábamos de acuerdo a los primeros brotes descritos. Probablemente se necesitaba un brote a gran escala y de larga duración como el actual que afecta a América Latina y Caribe para poner en evidencia sus complicaciones y población de riesgo.

La culpabilidad de este virus radica en su neurotropis$\mathrm{mo}^{10}$ responsable de los graves daños en el sistema neurológico del feto y algunas complicaciones en adultos como SGB- mielitis, meningoencefalitis. En este escenario, los esfuerzos deben estar destinados a proteger a las mujeres embarazadas de su contagio, ya sea evitando el viajar a zonas de riesgo o hacer uso de medidas de barrera en las relaciones sexuales durante todo el embarazo con parejas que hayan estado en zonas de riesgo o con antecedente de enfermedad. Para aquellas mujeres expuestas en zonas de trasmisión debe evitarse la picadura del mosquito usando repelentes adecuados para ellos y usar medidas de barrera en actividad sexual durante todo el embarazo.

Aún quedan muchas interrogantes por resolver, ¿cuál es el verdadero riesgo de transmisión congénita y el riesgo de complicaciones fetales?, ¿cuál es el rol que juega una persona con infección asintomática en la transmisión?, ¿cuál es el riesgo de complicaciones como infección congénita u otras enfermedades neurológicas y transmisión sexual en infectados asintomáticos?, ¿cuál es el riesgo de complicaciones tardías en hijos asintomáticos de madres con infección en el embarazo?. En fin, un largo camino aún de investigación para dar respuesta a estas interrogantes y contribuir a mitigar esta no mala sino terrible noticia de virus Zika y su impacto en la salud de la población naciente.

\section{Referencias bibliográficas}

1.- Oehler E, Watrin L, Larre P, Leparc-Goffart I, Lastere $\mathrm{S}$, Valour $\mathrm{F}$, et al. Zika virus infection complicated by Guillain-Barre syndrome-case report, French Polynesia, December 2013. Euro Surveill 2014; 19 (9). pii: 20720.

2.- Cao-Lormeau V M, Blake A, Mons S, Lastère S, Roche C, Vanhomwegen J, et al. Guillain-Barré syndrome outbreak associated with Zika virus infection in French Polynesia: a case-control study. Lancet $2016 \mathrm{Feb} 29$. pii: S0140-6736(16)00562-6. doi: 10.1016/ S0140-6736(16)00562-6. [Epub ahead of print]

3.- Tognarelli J, Ulloa S, Villagra E, Lagos J, Aguayo C, Fasce R, et al. A report on the outbreak of Zika virus on Easter Island, South Pacific, 2014. Arch Virol 2016; 161 (3): 665-8. doi: 10.1007/s00705-015-2695-5. Epub 2015 Nov 26.

4.- Cáceres C, Yung V, Araya P, Tognarelli J,
Villagra E, Vera L, et al. Complete nucleotide sequence analysis of a Dengue-1 virus isolated on Easter Island, Chile. Arch Virol 2008; 153 (10): 1967-70. doi: 10.1007/s00705-008-0200-0. Epub 2008 Sep 25.

5.- Zanluca C, Melo V C, Mosimann A L, Santos G I, Santos C N, Luz K. First report of autochthonous transmission of Zika virus in Brazil. Mem Inst Oswaldo Cruz 2015; 110 (4): 569-72.

6.- Cauchemez S, Besnard M, Bompard P, Dub T, Guillemette-Artur P, Eyrolle-Guignot D, et al. Association between Zika virus and microcephaly in French Polynesia, 2013-15: a retrospective study. Lancet 2016 Mar 15. pii: S0140-6736(16)00651-6. doi: 10.1016/ S0140-6736(16)00651-6. [Epub ahead of print].

7.- Schuler-Faccini L, Ribeiro E M, Feitosa I M, Horovitz D D, Cavalcanti D P, Pessoa A, et al. Possible association between Zika virus infection and microcephaly-Brazil, 2015. MMWR Morb Mortal Wkly Rep 2016; 65 (3): 59-62.

8.- Brasil P, Pereira J P Jr, Raja Gabaglia C, Damasceno L, Wakimoto M, Ribeiro Nogueira R M, et al. Zika virus infection in pregnant women in Rio de Janeiro-Preliminary report. N Engl J Med 2016 Mar 4. [Epub ahead of print].

9.- Meaney-Delman D, Hills S L, Williams C, Galang R R, Iyengar P, Hennenfent A K, et al. Zika virus infection among U.S. pregnant travelers-August 2015-February 2016. MMWR Morb Mortal Wkly Rep 2016; 65 (8): 211-4.

10.- Tang H, Hammack C, Ogden S C, Wen Z, Qian X, Li Y, et al. Zika virus infects human cortical neural progenitors and attenuates their growth. Cell Stem Cell 2016 Mar 4. pii: S1934-5909(16)00106-5. doi: 10.1016/j. stem.2016.02.016. [Epub ahead of print]. 